Article

\title{
The Relationship between CEO Governance and Social Responsibility of Service Firms
}

\author{
Sang-Hyun Ji ${ }^{1} \oplus$, Ki-Chang Yoon ${ }^{2}$, Joshua Park ${ }^{3} \mathbb{D}$, Sang-Bong An ${ }^{4}$ and Han-Mo Oh ${ }^{5, *}$ \\ 1 Division of Business and Commerce, Baekseok University, Chungcheongnam-do 31065, Korea \\ 2 Department of Business Administration, Kunsan National University, Jeollabuk-do 54150, Korea \\ 3 SolBridge International School of Business, Woosong University, Daejeon 34613, Korea \\ 4 Department of Business Administration, Shingyeong University, Gyeonggi-do 18274, Korea \\ 5 Department of International Trade, Chonbuk National University, 567 Baekje-daero, Deokjin-gu, \\ Jeonju-si Jeollabuk-do 54896, Korea \\ * Correspondence: ice1004@jbnu.ac.kr; Tel.: +82-063-270-3038
}

Received: 16 August 2019; Accepted: 6 September 2019; Published: 10 September 2019

check for updates

\begin{abstract}
Although it is widely accepted that corporate social responsibility (CSR) is key to obtaining business sustainability, there is a significant lack of empirical tests on the longer-term benefits of CSR in academic literature. The objective of our study was to examine the effects of chief executive officer (CEO) governance on CSR in service firms. We used CEO pay slice (CPS) to measure CEO governance and the Korea Economic Justice Institute Index (KEJI) to measure the level of CSR activities. CPS was measured using the compensation information of the board of directors in their business reports. The KEJI was obtained from the website of Citizens' Coalition for Economic Justice. The sample selected from listed firms consisting of 260 observations was collected from 2013 to 2015 at the TS-2000 and the FnGuide. The results showed that the CPS has a significant negative impact on the level of CSR activities in service firms. Specifically, CPS has a significant negative impact on the level of CSR activities in the areas of human, environment, and society at a significant level of one percent. Based on these results, higher CEO governance is expected to mean lower CSR in service firms. This paper contributes to the field of research in that it is the first research on the relationship between CEO governance and the level of CSR activities in service firms.
\end{abstract}

Keywords: business sustainability; service corporation; CEO power; CEO pay slice; corporate social responsibility

\section{Introduction}

It is widely accepted that corporate social responsibility (hereinafter referred to as CSR) is key to obtaining business sustainability. Nonetheless, there is a significant lack of empirical tests on the longer-term benefits of CSR in academic literature. CSR can be defined as activities carried out by a corporation, conducted voluntarily through a process of analyzing and accepting the social and environmental interests of its various stakeholders and actively applying them to the management of the corporation to fulfill the social duties that its stakeholders expect and demand of it [1]. Corporate social responsibility is not an activity that a company reluctantly imposes in response to external pressures or demands, but rather a process of voluntarily planning and implementing beneficial activities to adapt to the ethical standards and social expectations of its stakeholders and consumers. To accomplish this, companies must fulfill all legal requirements in the course of carrying out strategic CSR activities and aim at achieving public good that is beneficial to all members of society. For example, in most countries, businesses are regulated by laws to prevent their activities against the interests of society at large, and firm compliance with these legal requirements 
is the basis for carrying out corporate social responsibility. Corporate social responsibility goes beyond meeting just these basic legal requirements, to plan and implement additional voluntary CSR activities.

Since CSR activities are planned and executed voluntarily by the company, it has high likelihood of being influenced by internal decision making, especially by CEOs, who is the most dominant power figure within the company. The purpose of this study is to examine the difference a CEO's power makes in the level of a company's CSR activities. More specifically, we want to examine not only the overall CSR activities but also CSR activities divided into the following categories: (1) attention paid to people, (2) attention paid to the environment, and (3) attention paid to society. In other words, we want to verify the difference the governance of a CEO makes in a company's CSR activities-as a whole, and in the aspects of persons, environment, and society. To this end, CEO governance is measured by using the CEO pay slice (CPS) index [2]. CPS is a measure of the wage share of the CEO in comparison to the wages paid to the top five executives in terms of salary sequence. According to these studies [3-7], CEO compensation levels in a capitalist economy are an important indicator of their capability and governance levels; therefore, we also use CPS as the tool to measure CEO governance. Furthermore, the corporate social responsibility index is measured by using the Korea Economic Justice Institute Index (KEJI) of the Economic Justice Research Institute under the Citizens' Coalition for Economic Justice (CCEJ), following the practice of numerous previous studies [7-16]. While KEJI is composed of six evaluation items of soundness, fairness, consumer protection, employee satisfaction, social contribution, and environmental management, we exclude the evaluation standards focused on the corporation (soundness, fairness) and include only standards relevant to people, environment, and society in order to study the impact firms have on society. More specifically, we first utilize the entire KEJI index as an indicator of overall CSR. Second, we use the consumer protection and employee area of KEJI as indicators of attention to people. Third, we use the index of environmental management in KEJI to measure environmental concern. Fourth, we use the index of social contribution in KEJI to measure interest in society.

Meanwhile, the service industry has increasingly become a major industry in the post-industrialization society, and this trend is expected to continue into the future. Therefore, this study breaks away from the focus on manufacturing companies, instead focusing service industries, which are now more important than ever in this era of the 4th industrial revolution. Service companies tend to place more importance in enhancing their image compared to other industrial firms and face relatively greater internal and external pressures to perform CSR activities in response to changing social needs. Therefore, examining the difference made by the governance of a CEO, who is the highest decision-making power of the enterprise, on the level of CSR activities of firms is expected to be meaningful in that it provides further study of CSR activity factors. While prior studies on CSR activities have focused on the influence of large shareholders, foreign ownership, and institutional investor (national pension) in corporate governance structure, this study is expected to expand the research related to this field by focusing on CEO governance.

\section{Literature Review and Hypothesis Setting}

\subsection{Literature Review}

\subsubsection{Precedent Study on CEO Power}

The chief executive officer (CEO) is the top decision maker of a company with the position and authority as the company representative, representing the corporation externally and enforcing the resolution of the board of directors internally. While the norm is to have one CEO in a company, some have a plurality of CEOs. In some cases, the CEO may also serve as chairman, but in other cases, the two positions are separated. If the role of $\mathrm{CEO}$ and chairman are separated, the chairman generally exercises the power to preside over the board, whereas the CEO oversees the overall management. Therefore, it can be said that the executive authority on corporate management belongs to the CEO. The concentration of such authority on CEOs is likely to cause a dysfunctional management structure. For instance, when an inexperienced CEO monopolizes decisions on the development of technology 
and business models, and exerts authority on issues of finance, personnel, and marketing, problems in objective judgment may arise, with grave errors that can seriously affect the corporate image. Therefore, from 2000 onwards, companies worldwide have sought reforms to management structure reforms by creating roles that both support and provide a check and balance on CEO authority, such as chief financial officer (CFO), chief information protection officer (CPO), chief operating officer (COO), and content planning officer (CCO).

Nevertheless, in Korean companies, CEOs enjoy strong levels of authority, while the authority of CFOs, CPOs, COOs, and CCOs tend to have far more limited power. Therefore, domestic studies on decision makers have been focused on CEOs, but the issue of measuring CEO control has always been an issue of contention. Recently, a CPS(CEO Pay Slice) index has been proposed which is a simple and intuitive way to quantify the governance of the $\mathrm{CEO}$ by using $\mathrm{CEO}$ compensation information, leading to a number of studies being published using this index [2].

In Korea, with the amendment of the Capital Market Law in 2013, the annual salary information of executives with an annual salary of more than 500 million have been made public, leading to a number of domestic studies using CPS as an indicator of CEO governance.

The first domestic study [3] to apply the methodology we employ [2] used CPS to measure centralization of management (on CEO), concluding that firms with higher levels of centralization tend to have lower company value and have greater levels of ineffective decision making, such as excess investment. CPS was also applied to centralization of management, finding that capital costs are higher for firms with greater levels of centralization [4]. CPS was further used as an indicator of CEO influence, which demonstrated that the difference between accounting profit and taxable income was greater for firms with greater CEO influence, showing an adverse influence on management transparency [5]. A further study adapting CPS as an indicator of CEO influence reported that greater levels of CEO influence negatively affects the conservativeness of accounting, but that such effects can be limited to some degree through internal and external controls [6]. In summary, the results of studies that used CPS as an indicator of CEO influence concluded that larger levels of influence have a negative impact on the company.

\subsubsection{Precedent Study of Corporate Social Responsibility}

Corporate social responsibility (CSR) can be defined as activities carried out by a corporation, conducted voluntarily through a process of analyzing and accepting the social and environmental interests of its various stakeholders and actively applying them to the management of the corporation to fulfill the social duties that its stakeholders expect and demand of it. With the recent trend of increased recognition for corporate social responsibility, CSR activities are increasingly being counted as having economic value and accepted as important strategic means for creating value. Companies gain positive reputation through CSR activities, which not only increases enterprise value but also enhances the morale and loyalty of their members, thereby enhancing their productivity. This leads to improvements not only to the corporation but for the society at large.

Since 2010, interest in corporate social responsibility has increased in Korea, and various studies on CSR have accordingly been conducted. Early studies on CSR were mainly focused on research using the KEJI index of the CCEJ. More recently, research has been conducted about socially responsible investment applying the Korea Stock Exchange index [17,18], and about joint growth applying the joint growth index provided by the joint growth committee [19-26]. Among these, studies that utilize the same social responsibility measures (KEJI index) as the present study can be divided into studies that examine the influence of CSR activities [8-16,27] and those that examine factors that determine CSR activity levels. Specifically, findings from major domestic studies on factors that determine CSR activities similar to this study are as follows. Corporate size, debt ratio, profitability, ownership structure, age of enterprise, and association with a large-scale enterprise group are suggested as factors that affect social activity levels of firms [28]. Specifically, corporate size, corporate profitability, foreign investment share, and corporate age indicate higher CSR activities, while higher shareholder ownership and debt 
ratio indicate lower CSR activities. It was also reported that corporate ownership structure has an effect on CSR activities, that a higher foreign ownership ratio indicates more active CSR activities and that type of large shareholder (individual, financial institution, corporate) is related to levels of CSR activities [29]. The effect of the National Pension Service (NPS), which is the representative institutional investor in Korea, on corporate social responsibility activities was also examined, showing that the presence of NPS as investors with a stake of more than 5\% leads to greater CSR activities, thereby showing that the NPS is carrying out its monitoring role as a shareholder [30]. In this way, research has been carried out on the factors affecting corporate social responsibility activities in terms of corporate governance, but no studies researching the effects of CEOs have been reported, indicating a need in this field. In the case of service companies, the reputation of a company may have a direct impact on the profit generation of the enterprise, making CSR activities relatively more important for them. The purpose of this study is to examine the effect CEO influence has on CSR activities of service companies. As the first study that examines CEO influence on CSR activities of service companies, it is expected to add a new element to the existing body of research.

\subsection{Hypothesis Development}

The debate on corporate social responsibility can be divided broadly into two schools of thought. First is the shareholder theory, which maintains that management is primarily responsible for maximizing shareholder's profit within the framework of legality. Second is the stakeholder theory, which argues that corporate responsibility is part of the social system and should cover not only shareholders but also the interests of all stakeholders affected by the company. This distinction can be summarized by the question: "What is the proper relationship between a company and society?" Shareholder theorists would answer that firms have a duty to maximize profits within the framework of minimal moral constraints and laws, while stakeholder theorists would argue that companies have a broader obligation to society.

In the 1990s, when the General Electric's Jack Welch was promoting "maximization of shareholder value" as the management goal, companies placed maximum value on raising prices of shares through business performance and devoted all company resources to raise shareholder wealth. However, after the financial crisis of 2008, with the stock market bubble settling and the problems of maximizing shareholder value become more evident, management style concentrating on short-term performance and shareholder value began undergoing a structural reform. Since companies are made up of not only shareholders' assets but also assets of all members of the company including customers and products, it was recognized that management should cater to all of these stakeholders, and interest in corporate social responsibility began to increase. Now, the mainstream theory of corporate social responsibility has begun to shift from shareholder theory to stakeholder theory, and it is broadly accepted that corporations should go beyond merely pursuing profits within the legal framework; they should instead voluntarily engage in CSR activities to contribute to all members of the corporation and the society at large.

On the other hand, companies' voluntary CSR activities are likely to be influenced by internal decision-making factors, as they are not mandatory legal obligations. Previous studies have shown that CSR activities are influenced by internal corporate governance [28-30]. However, no studies have been reported on the impact of CEOs on CSR activities. More specifically, there have been no studies focused on service companies that are more sensitive to corporate image and reputation. As the CEO is the top decision maker of a company, it can be expected that the CEO would exert some influence on CSR activities as voluntary management activities. The purpose of this study is to examine the effect of CEO influence on CSR activities for service companies. In particular, we use the CEO pay slice (CPS) as a proxy variable of CEO governance [2] to determine how CEO influence affects the level of CSR activities. Thus far, studies using CPS [3-6] have generally found that the greater the governance of the CEO, the more negative impact it has on the business. In addition, companies with less corporate governance concentrated in CEOs have higher levels of CSR activities $[29,30]$ and companies with lower levels of major shareholders and higher levels of foreign shareholders have higher levels of shared growth [12]. Therefore, 
it can be expected that the level of CSR activities would be lower if decision-making power is concentrated in CEOs. As such, our research hypothesis is set as follows.

Hypothesis 1. CEO power in service firms will have a negative impact on its level of CSR activities.

Meanwhile, CSR activities (as discussed in the introduction above) can be divided into three aspects: (1) attention paid to people, (2) attention paid to the environment, and (3) attention paid to society. Therefore, this study divides CSR into these three aspects, and examines the effect of CEO governance on the CSR activities in each of these aspects. Our research hypotheses are as follows.

Hypothesis 1a. CEO power in service firms will negatively affect CSR activity levels of a company in terms of attention paid to people.

Hypothesis $1 \mathbf{b}$. CEO power in service firms will negatively affect CSR activity levels of a company in terms of attention paid to the environment.

Hypothesis 1c. CEO power in service firms will negatively affect CSR activity levels of a company in terms of attention paid to society.

\section{Research Method}

\subsection{Literature Review}

\subsubsection{Precedent Study on CEO Power}

The empirical analysis model of this study for hypothesis testing is as follows.

Level of CSR Activity (CSR, CSR_H, CSR_E, CSR_S $)_{i, t}=\alpha_{1}+\beta_{1}$ CPS(CEO Pay Slice) $)_{i, t}+\beta_{2}$ SIZE $_{i, t}$ $+\beta_{3} \mathrm{LEV}_{\mathrm{i}, \mathrm{t}}+\beta_{4} \mathrm{CFO}_{\mathrm{i}, \mathrm{t}}+\beta_{5} \mathrm{ROE}_{\mathrm{i}, \mathrm{t}}+\beta_{6} \mathrm{GRW}_{\mathrm{i}, \mathrm{t}}+\beta_{7} \mathrm{LOSS}_{\mathrm{i}, \mathrm{t}}+\beta_{8} \mathrm{OWN}_{\mathrm{i}, \mathrm{t}}+\beta_{9} \mathrm{FOR}_{\mathrm{i}, \mathrm{t}}+\beta_{10} \mathrm{BIG4}_{\mathrm{i}, \mathrm{t}}+\varepsilon_{\mathrm{i}, \mathrm{t}}$

CSR: Overall level of CSR activities (inclusion in KEJI)

CSR_H: CSR activities-Human level

(KEJI Consumer Protection and Employee areas)

CSR_E: CSR activities-Environment level

(KEJI Environmental management area)

CSR_S: CSR activities-Social level

(KEJI Social contribution area)

CPS: CEO pay slice

Control Variables:

SIZE: Size of corporation,

LEV: Debt ratio,

CFO: Operating cash flow,

ROE: Return on equity,

GRW: Asset growth rate,

LOSS: Loss in previous quarter,

OWN: Major shareholder ratio,

FOR: Foreign ownership,

BIG4: Audited by Big 4 .

According to the empirical analysis model, if $\beta_{1}$ shows a statistically significant negative value, our research hypothesis that CEO governance in service firms negatively affects CSR activity levels is supported. 


\subsubsection{CEO Pay Slice}

In applying CPS, the most important variables of interest in this study, we uses a version of the original research methodology [2] that was modified to fit the domestic environment [3], which calculates CPS based on the salary of an individual CEO in relation to that of the entire executive body (including the CEO). During the period of this study, companies in Korea were required to disclose the individual remuneration of registered executives whose total annual salary exceeds 500 million won, in accordance with the revision of the Capital Market Law in 2013. As such, it is difficult to decide whether executives to be included in the denominator of the CPS should be defined as top three or top five. However, since the average compensation for full-time officers including the CEO can be extracted through the business report, this study follows the practice of previous research [3] that calculates CPS by measuring CEO salary against the total salary of registered officers. More specifically, CEOs are defined as the executive with the highest rank among full-time executives that are listed as representing the company. The total amount of disbursements for full-time executive officers and the amount of compensation for the $\mathrm{CEO}$ are calculated using the individual executive compensation data disclosed in the business report, and then the ratio of CEO compensation to total executive officer compensation was measured to determine CPS [3]. Total compensation is measured by the total amount of cash compensation such as salary and bonuses, and retirement benefit is excluded from total compensation.

Since the annual salary is an important indicator of an individual's ability and governance under the capitalist economic system, the level of compensation the CEO receives as compared to other executives can be an indicator of the CEO governance. Therefore, in this study, we consider that the larger the CPS, the higher the governance of the CEO.

\subsubsection{Dependent Variable}

The dependent variable in this study is the indicator for the level of CSR activities, as described below. First, the overall CSR indicator is a dummy variable with a value of 1 if it is included in the KEJI 200 index, and a value of 0 otherwise. Second, attention to people was measured by the natural logarithm of the sum of the values of the consumer protection and the employee area in the KEJI index. Third, the environmental aspect of the KEJI index was measured by natural logarithm. Fourth, the aspect of attention to society was measured by natural logarithm of social contribution area in KEJI.

\subsubsection{Control Variables}

First, the firm size (SIZE) was measured as the natural logarithm of total assets. Second, the debt ratio (LEV) was measured as the ratio of assets to liabilities. Third, the operating cash flow (CFO) was measured as the ratio of operating cash flow to assets. Fourth, return on equity (ROE) was measured as the ratio of net profit to equity. Fifth, the asset growth rate (GRW) was measured as the ratio of assets increased from previous term assets. Sixth, the loss in previous term (LOSS) was a dummy variable that had a value of 1 if the company suffered losses, and a value of 0 if it did not. Seventh, the majority shareholding ratio $(\mathrm{OWN})$ was measured by dividing the total number of shares of major shareholders and related parties by the total number of ordinary shares issued. Eighth, foreign ownership (FOR) was measured by dividing the total number of shares of foreign investors by the number of common shares issued. Ninth, the size of auditor (BIG4) was a dummy variable having a value of 1 if the auditing corporation is one of Samil, Samjeong, Anjin, or HanYou, and 0 if it is not [31].

\subsection{Sample Selection}

In this study, we selected as samples service industries listed in the Korea Exchange, excluding finance service firms, whose individual remuneration information for registered officers paid more than 500 million KRW in remunerations was listed in the business report, as required by the Capital Markets Act of 2013. In effect, Korea provides an ideal context in which we may empirically test the hypotheses for the following reasons. First, Korea represents a semi-developed country and thereby may be effectively contrasted to an 
emerging country with relatively poor functional institutions or a developed country with well-established institutions in terms of capital, labor, and information. Second, in the Korean economy, service firms have substantially driven the economic growth. The service industries in this study include distribution (e.g., wholesale, retail), transportation, and telecommunications. Of the major categories (16) of the Korean Standard Industrial Classification Table (10), the following are included: D (electricity, gas, steam and air control supply industry [35]), G (wholesale and retail industry [45 47]), H (transportation and storage [49 52]), I (lodging and restaurants [55 56]), J (information and communication industry [58 63], M (professional, science, and technological services [70 73]), N (business facilities maintenance, business support, and rental services [74 76]), P (education service industry [85]) and R (arts, sports and leisure services [90 91]).

Individual executive compensation data were manually collected from the executive remuneration report on the company's business report, and KEJI was extracted from the data on the website of CCEJ. Other necessary financial data were extracted from the database of the listed companies' association (TS-2000) and the FnGuide. From the 629 total study samples, we excluded 344 samples that lacked CPS data, and 25 samples that had extreme values outside the mean \pm 3 (standard deviation) range. Therefore, the number of final research sampleswas 260 firms.

\section{Results of Empirical Analysis}

\subsection{Descriptive Statistics}

The following Table 1 provides descriptive statistics for our research sample service firms. First, the average value of the dummy variable for overall CSR levels (having a value of 1 or 0 based on whether the firm is listed on the KEJI top 200 list) was 0.224 , the average value of attention to people in the KEJI index (CSR_H) was 0.283, the average value of attention to environment (CSR_E) was 0.161, and the average value of attention to society (CSR_S) was 0.192. Second, the mean CPS value of the CEO was 0.491 , indicating that the CEO's wage share accounted for about $49.1 \%$ of the total remuneration of full-time executives. As the majority of the empirical analysis model variables do not exhibit large mean and median values considering standard deviation, we considered that it was reasonable to assume normal distribution [32].

Table 1. Descriptive statistics.

\begin{tabular}{cccccc}
\hline Variable & Mean & Median & SD & MIN & MAX \\
\hline CSR & 0.224 & 0.000 & 0.417 & 0.000 & 1.000 \\
CSR_H & 0.283 & 0.000 & 0.528 & 0.000 & 1.320 \\
CSR_E & 0.161 & 0.000 & 0.302 & 0.000 & 0.857 \\
CSR_S & 0.192 & 0.000 & 0.359 & 0.000 & 1.014 \\
CPS & 0.491 & 0.486 & 0.176 & 0.102 & 0.919 \\
SIZE & 27.487 & 27.459 & 1.517 & 24.056 & 31.476 \\
LEV & 0.464 & 0.465 & 0.190 & 0.036 & 0.934 \\
CFO & 0.057 & 0.051 & 0.062 & -0.113 & 0.296 \\
ROE & 0.046 & 0.045 & 0.075 & -0.218 & 0.327 \\
GRW & 0.035 & 0.034 & 0.085 & -0.249 & 0.273 \\
LOSS & 0.152 & 0.000 & 0.359 & 0.000 & 1.000 \\
OWN & 0.473 & 0.485 & 0.175 & 0.124 & 0.872 \\
FOR & 0.109 & 0.066 & 0.119 & 0.000 & 0.508 \\
BIG4 & 0.788 & 1.000 & 0.409 & 0.000 & 1.000 \\
\hline
\end{tabular}

\subsection{Correlation Analysis}

Table 2 shows the results of Pearson correlation analysis of the main variables of the empirical analysis model before hypothesis testing. First, Pearson correlation showed that in service firms, there is a negative correlation between CEO governance (CPS) and overall CSR with a 5\% significance level. Second, there is a negative correlation between CEO governance (CPS) and person-centered CSR 
activities in service firms, with a 5\% significance level. Third, there is a negative correlation between CEO governance (CPS) and environment related CSR activities in service firms, with a $5 \%$ significance level. Fourth, there is a negative correlation between CEO governance (CPS) and society related CSR activities in service firms, with a 5\% significance level. Therefore, it can be expected that larger levels of CEO governance in a service company will be linked to relatively lower levels of CSR activities.

Table 2. Pearson correlation analysis.

\begin{tabular}{|c|c|c|c|c|c|c|c|c|c|c|c|c|c|}
\hline & CPS & CSR & CSR_H & CSR_E & CSR_S & SIZE & LEV & CFO & ROE & GRW & LOSS & OWN & FOR \\
\hline CSR & $\begin{array}{c}-0.106^{*} \\
0.018\end{array}$ & & & & & & & & & & & & \\
\hline CSR_H & $\begin{array}{c}-0.108 * \\
0.016\end{array}$ & $\begin{array}{c}1.000 * * \\
0.000\end{array}$ & & & & & & & & & & & \\
\hline CSR_E & $\begin{array}{c}-0.093 \\
0.037\end{array}$ & $\begin{array}{c}0.996^{* *} \\
0.000\end{array}$ & $\begin{array}{c}0.995^{* *} \\
0.000\end{array}$ & & & & & & & & & & \\
\hline CSR_S & $\begin{array}{c}-0.101 \text { * } \\
0.024\end{array}$ & $\begin{array}{c}0.995^{* *} \\
0.000\end{array}$ & $\begin{array}{c}0.994^{* *} \\
0.000\end{array}$ & $\begin{array}{c}0.990 * * \\
0.000\end{array}$ & & & & & & & & & \\
\hline SIZE & $\begin{array}{c}0.398^{* *} \\
0.000\end{array}$ & $\begin{array}{c}-0.086 \\
0.055\end{array}$ & $\begin{array}{c}-0.090 \text { * } \\
0.045\end{array}$ & $\begin{array}{c}-0.064 \\
0.152\end{array}$ & $\begin{array}{c}-0.082 \\
0.069\end{array}$ & & & & & & & & \\
\hline LEV & $\begin{array}{c}0.126^{* *} \\
0.005\end{array}$ & $\begin{array}{c}-0.177^{* *} \\
0.000\end{array}$ & $\begin{array}{c}-0.174^{* *} \\
0.000\end{array}$ & $\begin{array}{c}-0.170 \text { ** } \\
0.000\end{array}$ & $\begin{array}{c}-0.180 * * \\
0.000\end{array}$ & $\begin{array}{c}0.324 * * \\
0.000\end{array}$ & & & & & & & \\
\hline $\mathrm{CFO}$ & $\begin{array}{l}0.041 \\
0.364\end{array}$ & $\begin{array}{c}0.133 \text { ** } \\
0.003\end{array}$ & $\begin{array}{c}0.126^{* *} \\
0.005\end{array}$ & $\begin{array}{c}0.132 * * \\
0.003\end{array}$ & $\begin{array}{c}0.136^{* *} \\
0.002\end{array}$ & $\begin{array}{l}0.036 \\
0.420\end{array}$ & $\begin{array}{c}-0.156^{* *} \\
0.000\end{array}$ & & & & & & \\
\hline ROE & $\begin{array}{l}0.029 \\
0.513\end{array}$ & $\begin{array}{c}0.291 \text { ** } \\
0.000\end{array}$ & $\begin{array}{c}0.287 \text { ** } \\
0.000\end{array}$ & $\begin{array}{c}0.288^{* *} \\
0.000\end{array}$ & $\begin{array}{c}0.293 * * \\
0.000\end{array}$ & $\begin{array}{c}-0.094 \\
0.036\end{array}$ * & $\begin{array}{c}-0.148^{* *} \\
0.001\end{array}$ & $\begin{array}{c}0.262 * * \\
0.000\end{array}$ & & & & & \\
\hline GRW & $\begin{array}{c}0.139 \text { ** } \\
0.002\end{array}$ & $\begin{array}{c}0.205^{* *} \\
0.000\end{array}$ & $\begin{array}{c}0.204^{* *} \\
0.000\end{array}$ & $\begin{array}{c}0.201 \text { ** } \\
0.000\end{array}$ & $\begin{array}{c}0.207^{* *} \\
0.000\end{array}$ & $\begin{array}{l}0.042 \\
0.354\end{array}$ & $\begin{array}{c}-0.126^{* *} \\
0.005\end{array}$ & $\begin{array}{c}0.257^{* *} \\
0.000\end{array}$ & $\begin{array}{c}0.329 * * \\
0.000\end{array}$ & & & & \\
\hline LOSS & $\begin{array}{c}-0.053 \\
0.234\end{array}$ & $\begin{array}{c}-0.201 * * \\
0.000\end{array}$ & $\begin{array}{c}-0.200 * * \\
0.000\end{array}$ & $\begin{array}{c}-0.200 \text { ** } \\
0.000\end{array}$ & $\begin{array}{c}-0.197^{* *} \\
0.000\end{array}$ & $\begin{array}{c}-0.113 \text { * } \\
0.012\end{array}$ & $\begin{array}{c}0.259 * * \\
0.000\end{array}$ & $\begin{array}{c}-0.224^{* *} \\
0.000\end{array}$ & $\begin{array}{c}-0.253^{* *} \\
0.000\end{array}$ & $\begin{array}{c}-0.264 * * \\
0.000\end{array}$ & & & \\
\hline OWN & $\begin{array}{c}-0.005 \\
0.916\end{array}$ & $\begin{array}{c}-0.162 * * \\
0.000\end{array}$ & $\begin{array}{c}-0.162 * * \\
0.000\end{array}$ & $\begin{array}{c}-0.158^{* *} \\
0.000\end{array}$ & $\begin{array}{c}-0.162 * * \\
0.000\end{array}$ & $\begin{array}{c}0.108 \text { * } \\
0.015\end{array}$ & $\begin{array}{c}-0.101 \text { * } \\
0.024\end{array}$ & $\begin{array}{c}-0.046 \\
0.308\end{array}$ & $\begin{array}{c}-0.029 \\
0.521\end{array}$ & $\begin{array}{l}0.026 \\
0.568\end{array}$ & $\begin{array}{c}-0.098^{*} \\
0.029\end{array}$ & & \\
\hline FOR & $\begin{array}{c}0.198^{* *} \\
0.000\end{array}$ & $\begin{array}{c}0.144^{* *} \\
0.001\end{array}$ & $\begin{array}{c}0.137^{* *} \\
0.002\end{array}$ & $\begin{array}{c}0.157^{* *} \\
0.000\end{array}$ & $\begin{array}{c}0.147^{* *} \\
0.001\end{array}$ & $\begin{array}{c}0.460 * * \\
0.000\end{array}$ & $\begin{array}{c}-0.054 \\
0.232\end{array}$ & $\begin{array}{c}0.256^{* *} \\
0.000\end{array}$ & $\begin{array}{c}0.173^{* *} \\
0.000\end{array}$ & $\begin{array}{c}0.156^{* *} \\
0.000\end{array}$ & $\begin{array}{c}-0.215^{* *} \\
0.000\end{array}$ & $\begin{array}{c}-0.352 * * \\
0.000\end{array}$ & \\
\hline BIG4 & $\begin{array}{c}0.297 \text { ** } \\
0.000\end{array}$ & $\begin{array}{l}0.020 \\
0.648\end{array}$ & $\begin{array}{l}0.017 \\
0.709\end{array}$ & $\begin{array}{l}0.027 \\
0.545\end{array}$ & $\begin{array}{l}0.018 \\
0.684\end{array}$ & $\begin{array}{c}0.544^{* *} \\
0.000\end{array}$ & $\begin{array}{c}0.153^{* *} \\
0.001\end{array}$ & $\begin{array}{l}0.044 \\
0.330\end{array}$ & $\begin{array}{c}-0.007 \\
0.884\end{array}$ & $\begin{array}{l}0.074 \\
0.099\end{array}$ & $\begin{array}{c}-0.135^{* *} \\
0.003\end{array}$ & $\begin{array}{c}0.150 \text { ** } \\
0.001\end{array}$ & $\begin{array}{c}0.308^{* *} \\
0.000\end{array}$ \\
\hline
\end{tabular}

The results of other control variables are as follows. First, the SIZE and CSR of service companies showed a negative correlation at the 10\% significance level. Second, the debt ratio (LEV) and overall CSR in service firms showed a negative correlation at the $1 \%$ significance level. Third, cash flow (CFO) and overall CSR showed a positive correlation at the $1 \%$ significance level. Fourth, return on equity (ROE) and CSR in service companies showed a positive correlation at the $1 \%$ significance level. Fifth, the asset growth rate (GRW) and overall CSR in service companies showed a positive correlation at the $1 \%$ significance level. Sixth, LOSS and CSR of service companies showed a negative correlation at the $1 \%$ significance level. Seventh, the ratio of large shareholders (OWN) and overall CSR showed a negative correlation at the $1 \%$ level. Eighth, the foreign shareholding ratio (FOR) and overall CSR in service companies showed a positive correlation at the $1 \%$ significance level. Ninth, the size of auditors (BIG4) and overall CSR of service firms showed a positive correlation, but not at statistically significant levels. However, the above correlation analysis results may be limited in interpretation as a result of not taking into account the influence of other control variables which may affect the relationship between the independent variable and the dependent variable.

\subsection{Result of Hypothesis Testing}

\subsubsection{Result for Hypothesis 1}

Table 3 shows the results of a logistic regression model on the relationship between CEO governance (CPS) and overall CSR in service firms to test Hypothesis 1 . Analysis reveals a negative relationship between CEO governance (CPS) and overall CSR levels in service firms at the $1 \%$ significance level. This shows that firms with higher levels of CEO governance have relatively lower levels of CSR activity, indicating that higher levels of CEO governance have a negative impact CSR activity. Therefore, Hypothesis 1 was supported. 
Table 3. Hypothesis 1 test results.

\begin{tabular}{cccc}
\hline \multirow{2}{*}{ Variable } & \multicolumn{3}{c}{ CSR } \\
\cline { 2 - 4 } & Coef. & Wald & $p$ \\
\hline CPS & -1.486 & 7.809 & 0.005 \\
SIZE & -0.028 & 0.047 & 0.828 \\
LEV & -2.315 & 9.086 & 0.003 \\
CFO & -1.879 & 0.826 & 0.363 \\
ROE & 9.933 & 18.969 & 0.000 \\
GRW & 3.574 & 4.548 & 0.033 \\
LOSS & -1.918 & 6.449 & 0.011 \\
OWN & -2.894 & 12.404 & 0.000 \\
FOR & -0.419 & 0.099 & 0.753 \\
BIG4 & 0.904 & 5.989 & 0.014 \\
Intercept & 1.012 & 0.101 & 0.751 \\
Nagelkerke R & & $0.292 * *$ & \\
Classification Accuracy & & $80 \%$ &
\end{tabular}

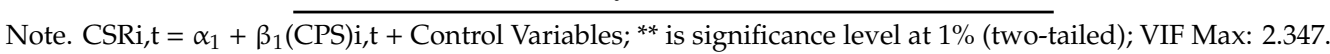

The following are the results of the control variables. First, the SIZE of service companies showed a negative relationship with CSR level, but not at statistically significant levels. Second, the debt-to-equity ratio (LEV) of service companies showed a negative relationship with CSR level at the $1 \%$ level. Third, the service cash flow (CFO) of service firms showed a negative relationship with CSR level, but not at statistically significant levels. Fourth, the return on equity (ROE) of service firms was positively related to CSR levels at the $1 \%$ level. Fifth, the asset growth rate (GRW) of service companies showed a positive relationship with CSR levels at the $5 \%$ level. Sixth, LOSS of service companies showed a negative relation with CSR levels at the $5 \%$ level. Seventh, the large shareholder ownership $(\mathrm{OWN})$ of service companies showed a negative relation with the CSR levels at $1 \%$. Eighth, foreign ownership (FOR) of service companies showed a negative relationship with overall CSR level, but not at statistically significant levels. Ninth, the size of auditor (BIG4) of service firms showed a positive relationship with the level of CSR at the $5 \%$ level.

\subsubsection{Result for Hypothesis 1a}

Table 4 shows the results of a linear regression model for the relationship between CEO governance (CPS) and people-related CSR activities (CSR_H) in service firms to test Hypothesis 1a. Analysis shows that CEO governance (CPS) in service companies have a negative relation with the CSR_H at the 1\% significance level. This shows that firms with higher levels of CEO governance have relatively lower levels of people-related CSR activity, indicating that higher levels of CEO governance has a negative impact people-related CSR activities. Therefore, Hypothesis 1a was supported. This section may be divided by subheadings. It should provide a concise and precise description of the experimental results, their interpretation as well as the experimental conclusions that can be drawn.

Table 4. Hypothesis 1a test results.

\begin{tabular}{cccc}
\hline \multirow{2}{*}{ Variable } & \multicolumn{3}{c}{ CSR } \\
\cline { 2 - 4 } & Coef. & $\mathbf{t}$ & $\boldsymbol{p}$ \\
\hline CPS & -0.269 & -3.072 & 0.002 \\
SIZE & -0.009 & -0.430 & 0.667 \\
LEV & -0.308 & -2.279 & 0.023 \\
CFO & -0.036 & -0.094 & 0.925 \\
ROE & 1.430 & 4.421 & 0.000 \\
GRW & 0.712 & 2.524 & 0.012 \\
\hline
\end{tabular}


Table 4. Cont.

\begin{tabular}{cccc}
\hline \multirow{2}{*}{ Variable } & \multicolumn{3}{c}{ CSR } \\
\cline { 2 - 4 } & Coef. & $\mathbf{t}$ & $\boldsymbol{p}$ \\
\hline LOSS & -0.158 & -2.334 & 0.020 \\
OWN & -0.586 & -3.886 & 0.000 \\
FOR & -0.012 & -0.044 & 0.965 \\
BIG4 & 0.127 & 1.958 & 0.051 \\
Intercept & 0.863 & 1.618 & 0.106 \\
F & & $10.184^{* *}$ \\
adjusted $R^{2}$ & & 0.150
\end{tabular}

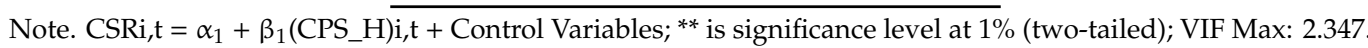

\subsubsection{Result for Hypothesis $1 \mathrm{~b}$}

Table 5 shows the results of a linear regression model for the relationship between CEO governance (CPS) and environment-related CSR activities (CSR_E) in service firms to test Hypothesis 1b. Analysis shows that CEO governance (CPS) in service companies have a negative relation with the CSR_E at the $1 \%$ significance level. This shows that firms with higher levels of CEO governance have relatively lower levels of environment-related CSR activity, indicating that higher levels of CEO governance have a negative impact environment-related CSR activities. Therefore, Hypothesis $1 \mathrm{~b}$ was supported.

Table 5. Hypothesis $1 \mathrm{~b}$ test results.

\begin{tabular}{cccc}
\hline \multirow{2}{*}{ Variable } & \multicolumn{3}{c}{ CSR } \\
\cline { 2 - 4 } & Coef. & $\mathbf{t}$ & $\boldsymbol{p}$ \\
\hline CPS & -0.147 & -2.912 & 0.004 \\
SIZE & -0.001 & -0.095 & 0.924 \\
LEV & -0.180 & -2.318 & 0.021 \\
CFO & 0.004 & 0.017 & 0.986 \\
ROE & 0.830 & 4.465 & 0.000 \\
GRW & 0.379 & 2.339 & 0.020 \\
LOSS & -0.085 & -2.192 & 0.029 \\
OWN & -0.321 & -3.707 & 0.000 \\
FOR & 0.031 & 0.206 & 0.837 \\
BIG4 & 0.067 & 1.807 & 0.071 \\
Intercept & 0.370 & 1.206 & 0.228 \\
F & & $9.800 * *$ & \\
adjusted $R^{2}$ & & 0.150 & \\
\hline
\end{tabular}

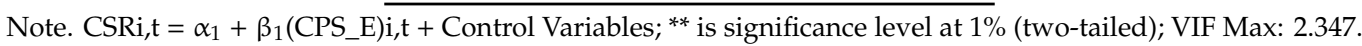

The following are the results of the control variables. First, the SIZE of service companies showed a negative relationship with the level of environmental CSR, but not at statistically significant levels. Second, the debt ratio (LEV) of service companies showed a negative relationship with environmental CSR levels at the 5\% level. Third, the service cash flow (CFO) of service firms showed a positive relationship with the environmental CSR level, but not at statistically significant levels. Fourth, the return on equity (ROE) of service companies showed a positive relationship with environmental CSR level at the $1 \%$ level. Fifth, asset growth rate (GRW) of service companies showed a positive relationship with environmental CSR level at the 5\% level. Sixth, LOSS of service companies showed a negative relation with the environmental CSR level at the $5 \%$ level of significance. Seventh, the majority shareholding ratio $(\mathrm{OWN})$ of service companies showed a negative relationship with the environmental CSR level at the $1 \%$ level. Eighth, foreign ownership rate (FOR) of service companies showed a positive relationship 
with the environmental CSR level, but not at statistically significant levels. Ninth, the size of auditor (BIG4) of service companies showed a positive relation with the environmental CSR level at the $10 \%$ level.

\subsubsection{Result for Hypothesis 1c}

Table 6 shows the results of a linear regression model for the relationship between CEO governance (CPS) and society-related CSR activities (CSR_S) in service firms to test Hypothesis 1c. Analysis shows that CEO governance (CPS) in service companies has a negative relation with the CSR_S at the 1\% significance level. This shows that firms with higher levels of CEO governance have relatively lower levels of society-related CSR activity, indicating that higher levels of CEO governance have a negative impact on society-related CSR activities. Therefore, Hypothesis 1c was supported.

Table 6. Hypothesis 1c test results.

\begin{tabular}{cccc}
\hline \multirow{2}{*}{ Variable } & \multicolumn{3}{c}{ CSR } \\
\cline { 2 - 4 } & Coef. & $\mathbf{t}$ & $\boldsymbol{p}$ \\
\hline CPS & -0.178 & -2.977 & 0.003 \\
SIZE & -0.004 & -0.248 & 0.805 \\
LEV & -0.228 & -2.481 & 0.013 \\
CFO & 0.027 & 0.103 & 0.918 \\
ROE & 1.004 & 4.561 & 0.000 \\
GRW & 0.480 & 2.504 & 0.013 \\
LOSS & -0.096 & -2.085 & 0.038 \\
OWN & -0.396 & -3.859 & 0.000 \\
FOR & 0.008 & 0.044 & 0.965 \\
BIG4 & 0.082 & 1.858 & 0.064 \\
Intercept & 0.514 & 1.415 & 0.158 \\
F & \multicolumn{3}{c}{$10.337 * *$} \\
adjusted $R^{2}$ & \multicolumn{3}{c}{0.158} \\
\hline
\end{tabular}

Note. CSRi,t $=\alpha_{1}+\beta_{1}($ CPS_S $)$ i, $t+$ Control Variables; ${ }^{* *}$ is significance level at 1\% (two-tailed); VIF Max: 2.347.

The following are the results of the control variables. First, SIZE of service companies showed a negative relationship with social CSR level, but not at statistically significant levels. Second, the debt ratio (LEV) of service companies showed a negative relationship social CSR at the 5\% significance level. Third, the service cash flow (CFO) of service firms showed a positive relationship with social CSR level, but not at statistically significant levels. Fourth, the return on equity (ROE) of service companies showed a positive relationship with social CSR at the $1 \%$ level. Fifth, asset growth rate (GRW) of service companies showed a positive relationship with social CSR at the 5\% level. Sixth, LOSS of service companies showed a negative relationship with social CSR at the $5 \%$ level of significance. Seventh, OWN of service companies showed a negative relationship with social CSR at the $1 \%$ level. Eighth, foreign ownership (FOR) of service companies showed a positive relationship with social CSR, but not at statistically significant levels. Ninth, the size of auditor (BIG4) of service firms showed a positive relationship with social CSR level at the $10 \%$ level.

The results of Tables 3-6 show that higher levels of CEO governance in service firms is connected to levels of corporate social responsibility activities. Therefore, the greater the influence of CEOs in service companies, the more likely they are to approach corporate social responsibility activities from the perspective of maximizing shareholder value rather than from the perspective of broader stakeholders.

\section{Conclusions}

This study examines the effect of CEO influence on corporate social responsibility activities in service companies. For this purpose, CEO pay slice (CPS) index [2] was used to measure CEO governance and CSR was measured using the KEJI index of the Economic Justice Research Institute under the Citizens 
Coalition for Economic Justice (CCEJ). More specifically, in addition to applying KEJI for overall CSR levels, KEJI indices for consumer protection and employee protection were used to measure people-related CSR activities, the KEJI index for environment was used to measure environment-related CSR activities, and the KEJI index for social contribution was used to measure society-related CSR activities. In addition, the research sample consisted of 232 service (excluding financial service companies) firms listed on the Korea Exchange from 2013 to 2015, in which the individual remuneration information of registered executives of more than 500 million won is publicly disclosed in the business report in accordance with the revision of the Capital Market Law in 2013.

The results of the analysis are as follows. First, CEO governance in service companies has a negative effect on the overall level of CSR activities. Second, CEO governance in service companies has a negative effect on people-related CSR activities. Third, CEO governance in service companies has a negative effect on environmental CSR activities. Fourth, the CEO governance in service companies has a negative effect on society-related CSR activities. These results show that CEO governance in service industries negatively affects the level of CSR activities. This can be interpreted as a result of various decision-making and control measures within and outside the company not providing restraints to the strong governance of the CEO. These findings are consistent with previous studies that show higher levels of corporate governance distribution being related to higher levels of CSR activities [29,30].

This study is meaningful in that it is the first study that examines the influence of CEO governance on CSR activities in service companies. This study is unique from previous studies in that it examines the relationship between CEO governance and CSR activities using CPS methodology [2]. In addition, this study is expected to provide various stakeholders with company information that will be helpful in understanding decision-making process related to CSR activities of service companies.

On the other hand, due to the fact that the sample period of this study is from 2013 to 2015, our sample is limited to measuring CPS for executives who are paid in excess of 500 million KRW. From 2018, compensation information of all officers, including those who are not registered, is required to be disclosed in the business report. Therefore, further research using CPS that includes unclassified officers is likely to be necessary. Furthermore, there may be a limit to its applicability to Korean firms in general or firms in other countries.

Author Contributions: S.-H.J. designed our research and analyzed data. S.-B.A. validated this analysis. J.P. wrote the original draft. H.-M.O. reviewed the draft and edited this article. K.-C.Y. conducted data curation and visualization. All authors equally contributed to this article.

Funding: This research received no external funding.

Acknowledgments: The authors are grateful to the three anonymous Sustainability reviewers, who have provided constructive ideas and insightful comments for this article.

Conflicts of Interest: The authors declare no conflict of interest.

\section{References}

1. Carroll, A.B. The Pyramid of Corporate Social Responsibility: Toward the Moral Management of Organizational Stakeholders. Bus. Horiz. 1991, 34, 39-48. [CrossRef]

2. Bebchuk, L.A.; Martijn, K.J.; Peyer, U.C. The CEO pay slice. J. Financ. Econ. 2011, 102, 199-221. [CrossRef]

3. Kwak, Y.M.; Kim, H.J. Managerial Centrality and Firm Value. Korean Account. Rev. 2017, 42, $187-226$. [CrossRef]

4. Moon, B.Y.; Chun, H.M. Managerial Centrality and Implied Cost of Equity Capital: Evidence from Korea. Account. Inf. Rev. 2018, 36, 109-133. [CrossRef]

5. Kim, J.Y.; Ji, S.H. The CEO Pay Slice (CPS) and Transparency of Business Administration: Utilizing Book-Tax Difference Information. Tax Account. Res. 2018, 58, 229-248.

6. Ji, S.H.; Kim, J.T. CEO Power and Accounting Conservatism: According to Governance, Internal Accounting Control System, Audit Quality. Korean Int. Account. Rev. 2019, 83, 127-157.

7. Yun, W.Y.; Ryu, Y.R.; Ji, S.H. The CEO Power and Earnings Management-Accounting and Real Earnings Management. J. Bus. Res. 2019, 34, 157-184. 
8. Lee, J.M.; Kim, Y. The Effects of Corporate Social Responsibility on Firm Value. Tax Account. Res. 2013, 35, 27-55.

9. Cho, M.K.; Kim, S.Y. The Effect of Corporate Social Responsibility on Earnings Quality. Tax Account. Res. 2014, 41, 213-231.

10. Kim, Y.H. The Effect of CSR on Earnings Management and Firm Value (Corporate Social Responsibility: CSR). Tax Account. Res. 2014, 40, 147-163.

11. Kang, K.Y. Analysis of the Relationship between the Performance of CSR and the Return in the Stock Market: Using ISO26000 as a Performance Index. Tax Account. Res. 2015, 45, 83-104.

12. Lee, S.C.; Kim, S.Y. The Effect of Corporate Social Responsibility on Cost Behavior. Tax Account. Res. 2015, 44, 209-226.

13. Kwon, H.S.; Park, J.W. The Effect of Corporate Social Responsibility on Accounting Information Quality Focused on Financial Industry. Tax Account. Res. 2016, 50, 193-211. [CrossRef]

14. Choi, S.B. Exploring the Relevance of Corporate Risk in the Light of Corporate Social Responsibility. Tax Account. Res. 2016, 50, 227-249. [CrossRef]

15. Kim, T.W. The Efficiency of Valuation and Persistence of Accruals and Cash Flows by the Level of Social Responsibility Activities. Tax Account. Res. 2018, 58, 25-55.

16. Kim, T.W.; Kim, J.W. Differentiative Market Response of Management Performance based on the Corporate Social Responsibility Activity. Tax Account. Res. 2018, 55, 95-114.

17. Ryu, Y.R.; Ji, S.H.; Lee, G.R. A Study on the Relevance between Socially Responsible Investment and Book-Tax Difference. J. Korea Conv. Soc. 2018, 9, 183-190.

18. Hwang, S.J.; Ryu, S.J. Relationships between SRI disclosure and business performance. J. Digit. Conv. 2018, 16, 137-145.

19. Kim, H.A.; Oh, K.W. Corporate Partnership Activity, Demand of External Audit and Value Relevance of Accounting Information. Account. Inf. Rev. 2016, 34, 433-457.

20. Lee, C.H.; Kwon, S.J. A Study on Factors Influencing the Level of Firm's Win-Win Growth-On Focusing Real Estate Policy. Tax Account. Res. 2018, 55, 161-186.

21. Ryu, Y.R.; Ji, S.H. A Study on the Relevance between the Corporate Governance and Win-Win Growth. J. Ind. Econ. Bus. 2018, 31, 1419-1442.

22. Ryu, Y.R.; Ji, S.H. A Study on the Earnings Management of Win-Win Growth Corporate: Utilizing Book-Tax Difference Information. Tax Account. Res. 2018, 57, 75-95.

23. Shin, Y.M. An Empirical Study on the Effect of Win-Win Growth Activity on Management Performance. J. Digit. Conv. 2018, 16, 71-78.

24. Kwak, Y.M.; Ji, S.H. A Study on the Accounting Conservatism of Win-Win Growth Corporate. Manag. Inf. Syst. Rev. 2019, 38, 155-168.

25. Ji, S.H. A Study on the Audit Quality of Win-Win Growth Corporate. J. Ind. Econ. Bus. 2019, 32, 553-580.

26. Ji, S.H.; An, S.B. A Study on the Real Earnings Management of Shared Growth Corporate. J. Int. Trade Commer. 2019, 15, 389-406.

27. Lee, Y.S. A Study on the Relationship between Corporate Social Responsibility Detailed Index and Tax Avoidance. Tax Account. Res. 2018, 57, 55-73.

28. Go, S.C.; Park, R.S. Corporate Social Responsibility and Firm Value. J. Tax. Account. 2011, 12, $105-134$.

29. Kim, S.H.; Jung, Y.K. The Monitoring Power of Foreign Ownership on Corporate Social Responsibility: Evidence from Korea. Korean Account. Rev. 2012, 37, 1-62.

30. Kim, Y.J.; An, J.I. The Effect of National Pension Blockholders on Corporate Social Responsibility. Korean Account. Rev. 2018, 43, 1-33. [CrossRef]

31. Park, J.H.; Ryu, Y.R. The Impact of Investment Tendency of Foreign Investor on the Audit Quality. Tax Account. Res. 2018, 57, 165-184.

32. Ji, S.H. The Effect of the Investor Relation on Real Earnings Management-According to Firm's Governance and Audit Quality. Tax Account. Res. 2018, 55, 29-52.

(C) 2019 by the authors. Licensee MDPI, Basel, Switzerland. This article is an open access article distributed under the terms and conditions of the Creative Commons Attribution (CC BY) license (http://creativecommons.org/licenses/by/4.0/). 